\title{
Episodic Particulate Sulfate and Sulfur Dioxide on the Southwestern Japan Coast in March and April 2010
}

\author{
Tetsuji Nagatani, Maromu Yamada ${ }^{1)}$, Tomoko Kojima ${ }^{2)}$ and Daizhou Zhang* \\ Faculty of Environmental and Symbiotic Sciences, Prefectural University of Kumamoto, Tsukide 3-1-100, Kumamoto 862-8502 \\ Kumamoto, Japan \\ ${ }^{1)}$ Center for Innovation, Kanazawa University, Kanazawa, Ishikawa 920-1192, Japan \\ ${ }^{2)}$ Graduate School of Science and Technology, Kumamoto University, Kurokami 2-39-1, Kumamoto 860-8555, Japan
}

*Corresponding author. Tel: +81-96-321-6712, E-mail: dzzhang@pu-kumamoto.ac.jp

\begin{abstract}
Particulate sulfate in $\mathrm{PM}_{2.5}$, sulfur dioxide $\left(\mathrm{SO}_{2}\right)$ and size-segregated aerosol particle number concentrations were measured at a site $\left(32^{\circ} 19^{\prime} \mathrm{N}, 129^{\circ} 59^{\prime} \mathrm{E}\right)$ on the southwestern Japan coast from 5 March to 10 April, 2010. Results show frequent episodic increases of sulfate and $\mathrm{SO}_{2}$. Compared to the average concentration of sulfate $4.4 \pm 2.7 \mu \mathrm{g} \mathrm{m}^{-3}$ in the whole observation period, episodic sulfate reached $10.5-20.1 \mu \mathrm{g}$ $\mathrm{m}^{-3}$. The variation of sulfate always synchronized with aerosol particles in the size range of 0.1-0.5 $\mu \mathrm{m}$, indicating the episodic sulfate was a consequence of the increase of the sub-micron particles. $\mathrm{SO}_{2}$ did not have remarkable increase in any episodes of sulfate increase. During the passage of low pressure systems which loaded Asian dust in postfrontal air, concentrated sulfate appeared right behind the front but before dust arrival, suggesting the dominance of dustfree particulate sulfate. Weather and backward trajectory analyses revealed that air parcels with high sulfate passed eastern and northeastern China or Korean peninsula before arriving at the site. In contrast, those with high $\mathrm{SO}_{2}$ passed an active volcano, Mt. Sakurajima, about $100 \mathrm{~km}$ in the south, suggesting the $\mathrm{SO}_{2}$ was more likely from the volcanic emission. The ratio of sulfate to total sulfur compounds $\left(\mathrm{SO}_{4}{ }^{2-}\right) /\left(\mathrm{SO}_{4}{ }^{2-}+\mathrm{SO}_{2}\right)$ was $0.31-0.89$ in continentally originated air while was $0.25-0.43$ in the air having passed the volcano, showing more efficient conversions of $\mathrm{SO}_{2}$ to sulfate in the air from the continent. The close dependence of the conversion on humidity in the continentally originated air was confirmed.
\end{abstract}

Key words: Sulfur compounds, East Asia, Anthropogenic source, Volcanic emission, Asian dust

\section{INTRODUCTION}

Sulfur-containing compounds play an important role in climate change on a global scale and also in air pollution in regional and local scales. They are emitted into the atmosphere from natural and anthropogenic sources. Estimates showed that the total sulfur emission was approximately $98-120 \mathrm{Tg}(\mathrm{S}) \mathrm{yr}^{-1}$, and anthropogenic emission mainly in the state of sulfur dioxide $\left(\mathrm{SO}_{2}\right)$ from fossil-fuel combustion in power plants, industries and traffic was 73-80 Tg (S) $\mathrm{yr}^{-1}$ (Seinfeld and Pandis, 1998). Major sources of natural emissions include dimethylsulfiede (DMS) from ocean surface and $\mathrm{SO}_{2}$ from volcanic emissions and they contribute approximate $15-25 \mathrm{Tg}(\mathrm{S}) \mathrm{yr}^{-1}$ and 9.3-11.8 $\mathrm{Tg}(\mathrm{S}) \mathrm{yr}^{-1}$, respectively (Seinfeld and Pandis, 1998; Lovelock et al., 1972). The oxidation of $\mathrm{SO}_{2}$ and DMS in the atmosphere transfers these species eventually into sulfate, which is the primary precursor gaseous species to initiate secondary particle formation in the natural atmosphere. Sulfate particles substantially influence the distribution of solar radiative energy in the air directly by scattering and absorbing sunlight and indirectly by acting as cloud condensation nuclei (Chuang et al., 1997; Charlson et al., 1992).

In general, $\mathrm{SO}_{2}$ emissions in populated areas are mainly from anthropogenic activities. In contrast, the concentration of nuclei in the remote marine atmosphere is largely controlled by DMS emissions from the sea surface (Savoie and Prospero, 1989). Besides, large volcanic eruptions such as Pinatubo eruption injected $\mathrm{SO}_{2}$ directly into the stratosphere, where the gaseous species was gradually converted to sulfate aerosols (Robock, 2000; Solomon, 1999). $\mathrm{SO}_{2}$ is oxidized by $\mathrm{OH}$ to produce gas-phase sulfuric acid $\left(\mathrm{H}_{2} \mathrm{SO}_{4}\right)$ in the atmosphere, and part of the $\mathrm{H}_{2} \mathrm{SO}_{4}$ is in turn neutralized by other species such as ammonia to produce salt such as ammonium sulfate. $\mathrm{H}_{2} \mathrm{SO}_{4}$ and its neutralized substance, via nucleation, produce new particles in the 
atmosphere. The lifetime of $\mathrm{SO}_{2}$ against reaction with $\mathrm{OH}$ is about 1-2 weeks. Atmospheric oxidation of $\mathrm{SO}_{2}$ also takes place by $\mathrm{H}_{2} \mathrm{O}_{2}$ in the clouds. $\mathrm{SO}_{2}$ was removed rapidly by aqueous phase reactions and transformed into sulfate (Hewitt, 2001; Jacob, 1999). Another important process for $\mathrm{SO}_{2}$ conversion to sulfate is the heterogeneous reactions on pre-existing airborne particles, such as droplets, sea salt, mineral particles and soot (Seinfeld and Pandis, 1998). This process sometimes contributes substantially to the formation of sulfate in the air in particular when it is heavily polluted by particulate matters (Dentener et al., 1996; Luria and Sievering, 1991).

Anthropogenic emission of air pollutants in East Asia is a public concern. $\mathrm{SO}_{2}$ emission in this area is one of the most substantial sources of $\mathrm{SO}_{2}$ in the Asian continent and it contributed approximately $66 \%$ of total Asian $\mathrm{SO}_{2}$ emission (Zhang et al., 2009). $\mathrm{SO}_{2}$ emission in China slowly declined between 1996 and 1999 because of the reduction of fuel consumption due to the Asian economic downturn (Streets et al., 2003, 2000). However, it increased by 53\% from 2000 to 2006 because of the rapid economic growth (Lu et al., 2010; Zhang et al., 2009; Ohara et al., 2007). It has been confirmed that that the westerlies in the middle latitude of northern hemisphere brought $\mathrm{SO}_{2}$ or its subsequent products into downstream areas although the concentration of $\mathrm{SO}_{2}$ observed in Japan was much smaller than that in China (Igarashi et al., 2004).

Transport and dispersion of anthropogenic $\mathrm{SO}_{2}$ and sulfate in the outflow of the Asian continent in the downstream areas have been extensively investigated by field observations (e.g. Sahu et al., 2009; Hatakeyama et al., 2004; Koike et al., 2003) and model simulations (e.g. Heald et al., 2006; Takemura et al., 2003; Uno et al., 2003). Anthropogenic pollutants such as nss- $\mathrm{SO}_{4}{ }^{2-}$, nitrate and mineral dust showed a spring maximum at North Pacific area (Prospero and Savoie, 2003; Prospero et al., 1989). The air parcels from Asian continent arrived at central Pacific in 2-3 days (Tu et al., 2004) and on the western coast of the United States in $\sim 7$ days (Jaffe et al., 1999; Andreae et al., 1988). Model study by Takemura et al. (2003) suggested that the contribution of the anthropogenic aerosol, such as carbonaceous and sulfate particles, to the total optical thickness was comparable to that of Asian dust. However, the observational data on sulfur compounds, in particular sulfate, in Asian continental flow are far less adequate for the investigation of their environmental impacts and model validations.

In the spring 2010, we conducted a short-term observation campaign at a coastal site in southwestern Japan, where no locally anthropogenic emissions of sulfur compounds were expected. $\mathrm{SO}_{2}$, particulate sul- fate and size-segregated number concentrations of aerosol particles larger than $0.1 \mu \mathrm{m}$ were in situ observed. Episodic increases of $\mathrm{SO}_{2}$ and sulfate were frequently encountered. We found that the episodic increase of sulfate was likely from the outflow of Asian continent whereas that of $\mathrm{SO}_{2}$ was caused by the emission of volcanic activities. In this paper we report these results and discuss the transformation of $\mathrm{SO}_{2}$ to sulfate in the outflow of Asian continent based on our observational data.

\section{OBSERVATION AND DATA ANALYSIS}

An observatory, named Amakusa Environmental Research Unit (AERU), was developed at the west coast of Amakusa Island, Kumamoto Japan $\left(32^{\circ} 19^{\prime} \mathrm{N}, 129^{\circ}\right.$ $59^{\prime} \mathrm{E}, 35 \mathrm{~m}$ asl.). Fig. 1 shows its geographic position. There are no industries and factories in this area and local anthropogenic emissions of sulfur compounds are not expected. When air parcels are from west, northwest, southwest and south directions, any pollutants in the air can be considered as non-locally originated matters. Therefore, the site is quite suitable to observing atmospheric pollutants flowing into the areas from other places. Its $100 \mathrm{~km}$ northeast is the city of Kumamoto with a population of 0.7 million, $350 \mathrm{~km}$ northwest is the southmost of Korean peninsula, $800 \mathrm{~km}$ west is the coastal area of eastern China with mega cities such as Shanghai, and $1500 \mathrm{~km}$ northwest is a cluster area in northern China with mega cities such as Beijing. There are two active volcanoes, where volcanic gases and ashes are constantly emitted and may influence the atmospheric composition at AERU. One is Mt. Sakurajima, about $110 \mathrm{~km}$ in the south, and the other is Mt. Aso, about $140 \mathrm{~km}$ in the northeast (Fig. $1)$.

The observations were carried out at AERU between 5 March and 10 April 2010. Number concentrations of atmospheric aerosol particles were measured every 15 minutes from 5 March to 6 April using two optical particle counters, Rion KC-01D and KC-18 (Rion Corporation, Japan). The size ranges of aerosol particles measured with Rion KC-18 are >0.1, 0.15, 0.2, 0.3 and $0.5 \mu \mathrm{m}$ diameter, and those with Rion-KC01D are $>0.3,0.5,1.0,2.0$ and $5.0 \mu \mathrm{m}$ diameter. The Rion KC18 was operated with an automatic diluting unit (Rion KD-06), which diluted the aerosol particle concentration into $1 / 100$ before being measured by the Rion $\mathrm{KC}$ 18. The flow rate of Rion KC-01D was $0.5 \mathrm{~L} \mathrm{~min}{ }^{-1}$ and that of Rion $\mathrm{KC}-18$ was $0.3 \mathrm{~L} \mathrm{~min}^{-1}$. A cascade impactor with its jet nozzle diameter $1.0 \mathrm{~mm}$ was fixed at the inlet tube to Rion KD-06 and Rion KC-18 to re- 


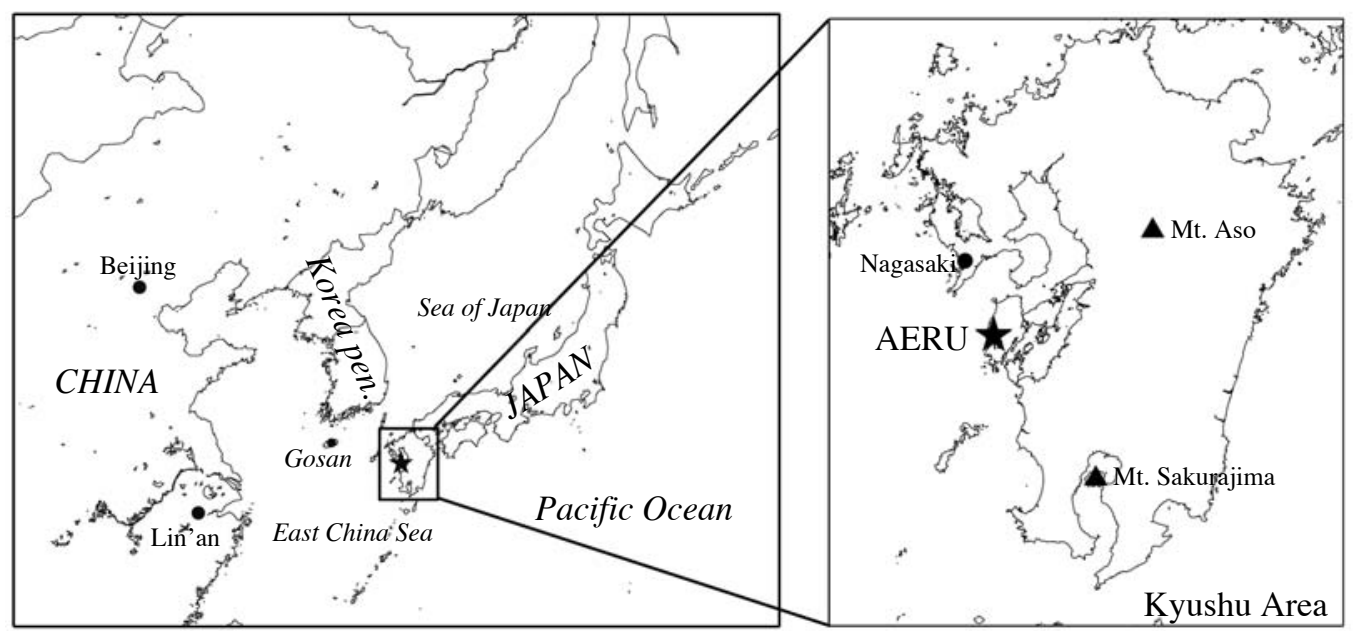

Fig. 1. Location of the observatory, Amakusa Environmental Research Unit (AERU).

move large particles. Estimation with the flow rate revealed that particles larger than $2.3 \mu \mathrm{m}$ were efficiently trapped by the impactor. The concentration of sulfur dioxide $\left(\mathrm{SO}_{2}\right)$ was measured every 15 minutes by a UV fluorescence instrument (Thermo Environmental Instruments, USA, Model 43C-TL) at a flow rate of $0.5 \mathrm{~L} \mathrm{~min}^{-1}$. The detection limit of $\mathrm{SO}_{2}$ were $0.5 \mathrm{ppbv}$. The concentration of sulfate in particles smaller than $2.5 \mu \mathrm{m}$ aerodynamic diameter $\left(\mathrm{PM}_{2.5}\right)$ was measured every 20 minutes by using a Sulfate Particulate Analyzer (Thermo Environmental Instruments, USA, Model $5020 \mathrm{SPA}$ ) at a flow rate of $0.5 \mathrm{~L} \mathrm{~min}^{-1}$. This instrument thermally converts sulfate to gaseous $\mathrm{SO}_{2}$ in the thermal reduction oven operating at 1000 degrees, measures the $\mathrm{SO}_{2}$ concentration by a pulsed UV fluorescence analyzer, and then calculates the mass concentration of particulate sulfate (Schwab et al., 2006). Ambient air was introduced into these instruments from inlets which were fixed at $60 \mathrm{~cm}$ above the roof of the unit. Teflon tubes were applied for the measurements of particle number concentrations and $\mathrm{SO}_{2}$ and a copper tube for sulfate. The length of the tubes for the measurements of particle number concentration, $\mathrm{SO}_{2}$ concentration, and sulfate concentration was approximately $1.5 \mathrm{~m}, 2.0 \mathrm{~m}$, and $2.5 \mathrm{~m}$, respectively.

Local meteorological records including pressure, temperature, relative humidity, precipitation, wind speed and direction were obtained from the Ushibuka Local Meteorological Observatory $\left(32^{\circ} 12^{\prime} \mathrm{N}, 130^{\circ}\right.$ $33^{\prime} \mathrm{E}, 3 \mathrm{~m}$ asl.), which is an official meteorological observatory of Japan Meteorological Agency and located about $15 \mathrm{~km}$ of AERU on the southern coast of Amakusa Island.

For comparing the obtained data with weather condition, we referred to weather charts publicly opened by the Japan Meteorological Agency. Isentropic backward trajectories of air parcels approaching AERU during the observation period were calculated by using the on-line NOAA HYSPLIT (Hybrid Single-particle Librarian Integrated Trajectory) model (Draxler and Rolph, 2003) at NOAA Air Resources Laboratory's website (http://ready.arl.noaa.gov/HYSPLIT_traj.php).

\section{RESULTS AND DISCUSSION}

Fig. 2 shows the time series of one-hour averaged sulfate, $\mathrm{SO}_{2}$ and particle number concentrations in the observation period. For reference of weather, surface meteorological conditions of sea-level pressure, precipitation, temperature, relative humidity, wind speed and direction are also shown in the figure. Cold front passages are marked by dotted lines. The weather changed alternatively by low and high pressure systems with periods of a few days, which resulted from the passage of cyclones and anticyclones in the middle latitude westerly of northern hemisphere. This is the typical weather in this area in spring. As a consequence, air parcels at AERU during this period were frequently from the Asian continent and a few from other areas. Asian dust events are also frequently encountered in this area in springtime. In this study, presence of Asian dust in the atmosphere was identified by high concentration of coarse aerosol particles. We regard Asian dust intrusions to have happened when the concentration of particles larger than $5 \mu \mathrm{m}$ became higher than 100 particles $\mathrm{L}^{-1}$. This occurred on $16,20-21$ March and 3 April (Fig. 2(b)).

Sulfate, sulfur dioxide and aerosol concentrations increased and decreased in response to the change of 


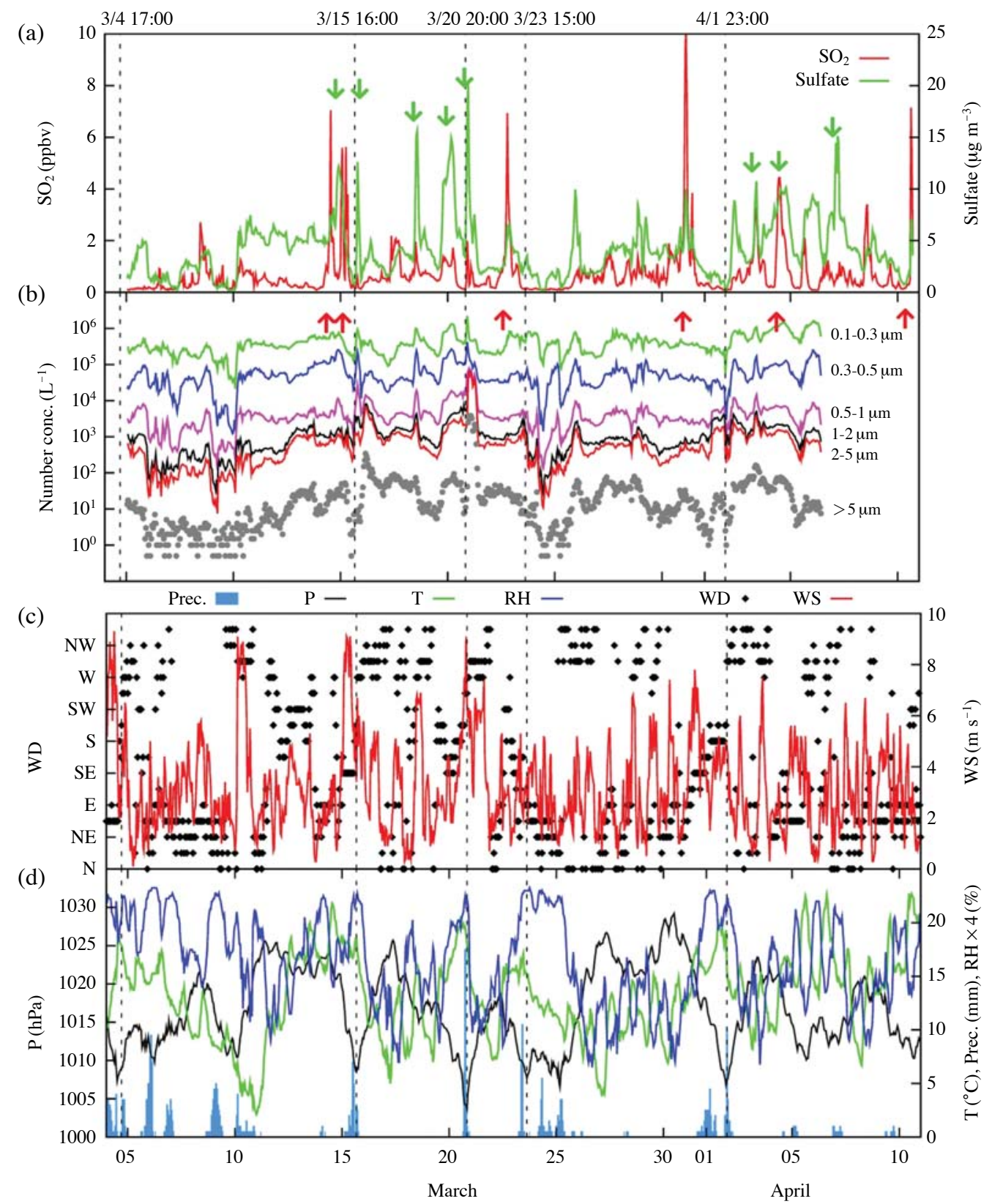

Date (JST)

Fig. 2. Time series of $\mathrm{SO}_{2}$ and sulfate in $\mathrm{PM}_{2.5}$ (a), aerosol number concentrations (b) at AERU, wind direction and speed (c) and precipitation, pressure, temperature and relative humidity (d) at the Ushibuka Regional Meteorological Observatory from 5 March to 10 April 2010. Passages of cold fronts are indicated by dotted lines.

the weather. Since precipitation could result in efficient removal of those matters and the removal efficiencies were unknown, records of sulfate, $\mathrm{SO}_{2}$ and aerosols in precipitation periods were excluded in data analysis and processing and are not included in the following description and discussion. Table 1 shows the statistical results of sulfate and $\mathrm{SO}_{2}$ concentrations within the whole observation period after extracting data when there was precipitation at Amakusa.

Sulfate concentration was usually less than $5 \mu \mathrm{g} \mathrm{m}^{-3}$. However, there were episodic short-time increases. Although the average sulfate concentration during the entire observation period was $4.4 \pm 2.7 \mu \mathrm{g} \mathrm{m}^{-3}$, sulfate concentration exceeded $10 \mu \mathrm{g} \mathrm{m}^{-3}$ in 8 periods (marked 
by green arrows in the figure: around 14, 15, 18, 1920, 20-21 March, and 3, 4, 7 April). Maxima in these episodes reached 10.1-20.1 $\mathrm{g} \mathrm{m} \mathrm{m}^{-3}$ and the time of high sulfate lasted for 4-20 hours. Since we did not measure chemical compositions of aerosol particles, it is uncer-

Table 1. The statistics of $\mathrm{SO}_{2}$ and sulfate concentrations observed at AERU from 5 March to 10 April 2010, along with meteorological data recorded at the Ushibuka Regional Meteorological Observatory during the period. Data influenced by precipitation were excluded.

\begin{tabular}{lccccc}
\hline & Min & Median & Mean & Max & SD \\
\hline $\mathrm{SO}_{2}(\mathrm{ppbv})$ & 0.08 & 0.51 & 0.77 & 10.27 & 1.00 \\
Sulfate $\left(\mu \mathrm{g} \mathrm{m}^{-3}\right)$ & 0.07 & 3.91 & 4.37 & 20.09 & 2.67 \\
Pressure $(\mathrm{hPa})$ & 1004 & 1017 & 1017 & 1022 & 5.43 \\
Temperature $\left({ }^{\circ} \mathrm{C}\right)$ & 2.1 & 12.7 & 12.71 & 22.5 & 3.92 \\
$\mathrm{RH}(\%)$ & 26 & 65 & 64.83 & 93 & 17.34 \\
$\mathrm{WS}(\mathrm{m} / \mathrm{s})$ & 0.1 & 2.8 & 3.19 & 9.1 & 1.82 \\
\hline
\end{tabular}

tain how much sea salt contributed to the sulfate concentration. According to the previous studies, sea-salt related sulfate in particulate matters usually occupied only a small fraction in total sulfate in this area when the air parcels were from the Asian continent (Hatakeyama et al., 2004; Koike et al., 2003).

Whenever sulfate showed a remarkable increase, $\mathrm{SO}_{2}$ also increased a little with the maximum concentrations usually smaller than 2 ppbv. However, besides those accompanying sulfate increases, $\mathrm{SO}_{2}$ had shortterm remarkable increases. The mean $\mathrm{SO}_{2}$ concentration during the observation period was $0.77 \pm 1.00$ ppbv, but $\mathrm{SO}_{2}$ concentration exceeded 4 ppbv in 6 short periods (marked by red arrow in the figure: around 14, 15, 22, 31 March, and 4, 10 April). The remarkable increases of $\mathrm{SO}_{2}$ appear to be weakly related to sulfate although they were also accompanied by only a little increases of sulfate, except two periods around 15

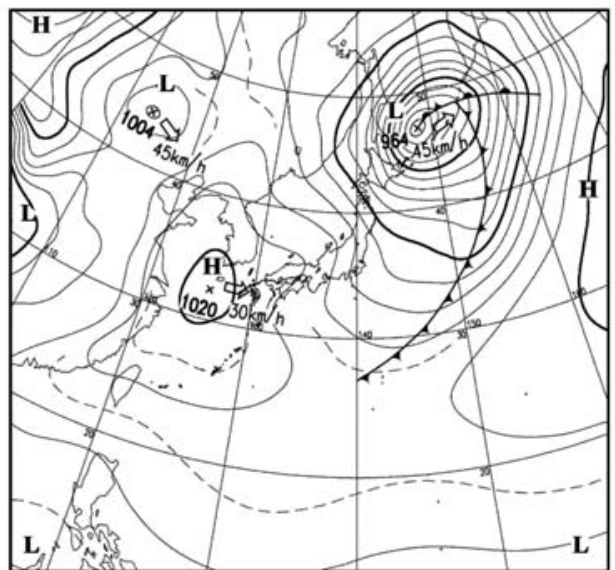

(a)

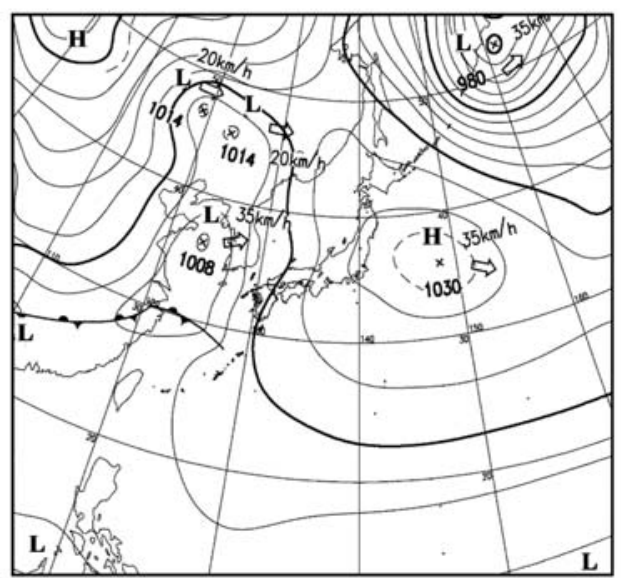

(c)

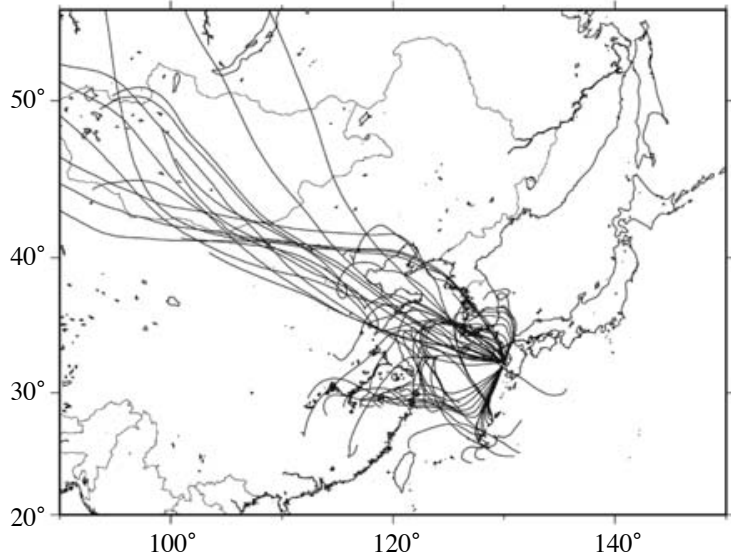

(b)

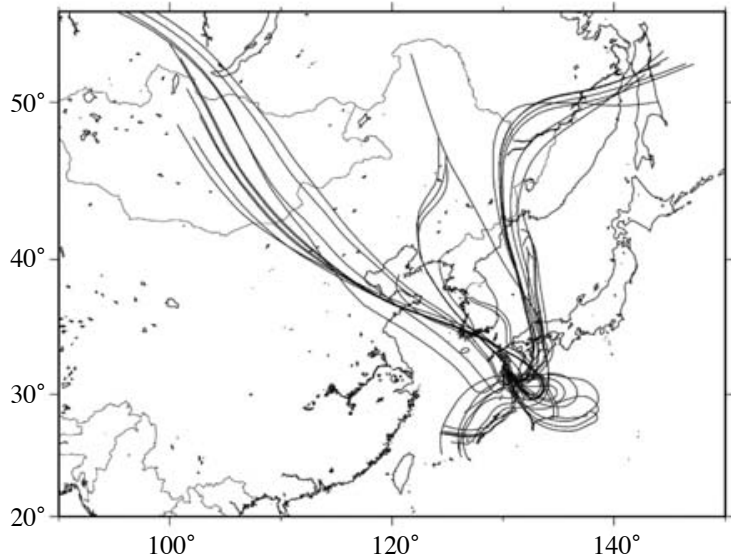

(d)

Fig. 3. Surface weather chart for postfrontal case (0300 21 March 2010) (a) and prefrontal case (0300 15 March 2010) (c), and backward trajectories for high sulfate events on 15, 18, 19-20, 20-21, 25-26 March, 2, 3 5-6 and 6-7 April 2010 (b) and high SO events on 14, 15, 22, 30, 31 March, 4 and 10 April 2010 (d). All trajectories were started at the altitude $500 \mathrm{~m}$. 
March when an increase of $\mathrm{SO}_{2}$ was apparently interrupted and separated into two by an increase of sulfate.

The number concentration of aerosol particles in the range of 0.1-0.5 $\mu \mathrm{m}$ always synchronized with increase and decrease of sulfate. However, particles larger than $1 \mu \mathrm{m}$, that are usually dominated by mineral (Asian dust) and sea-salt particles in this area (Zhang et al., 2006), did not always follow the pattern of variation of sulfate (e.g. the period of 15-16 March when sulfate remarkably increased). This indicates that the sulfate was present principally in sub-micron particles.

\section{1 Episodic Increase of Sulfate}

During the observation period, four cyclones with cold fronts passed over the observation area and cold fronts also swept the south part of Kyushu area on 6, 9, 24 March and from 5 to 9 April. Weather conditions such as pressure, temperature and wind direction changed drastically before and after the frontal passages. Sulfate and aerosol number concentrations showed episodic increases around the passages of cyclones. Fig. 3 shows examples of surface weather charts of postand prefrontal cases and isentropic backward trajectories for high sulfate and $\mathrm{SO}_{2}$ episodes. Air parcels with high sulfate concentration were characterized by continental origins. The increases of sulfate appeared in the postfrontal air on 15, 20-21 March and 2 April when the air came from eastern or northeastern China. Some of the increases were accompanied by Asian dust in postfrontal air on 16, 20, 21 March and 3 April. In these cases, the pressure decreased more than 10 $\mathrm{hPa}$ within 24 hours and the relative humidity rapidly declined by $\sim 40 \%$. Wind direction changed from westerly to northwesterly within short periods. On the other hand, the high-sulfate episode on 19-20 March appeared in the prefrontal air. The backward trajectories indicate that the air parcels were from eastern or southeastern China.

It is noted that increases of sulfate were also observed in periods between frontal passages. For example, increases of sulfate with a little increased $\mathrm{SO}_{2}$ were observed on 17-18 March. Sulfate and $\mathrm{SO}_{2}$ concentrations remained approximately constant until the pressure started to decline. After that, the low-pressure approached Japan from eastern China. Atmospheric pressure reached maximum at 0900 on 17 March, and then gradually decreased. $\mathrm{SO}_{2}$ concentration slightly increased during 0800-1900 on 17 March when relative humidity showed very low values. A remarkably
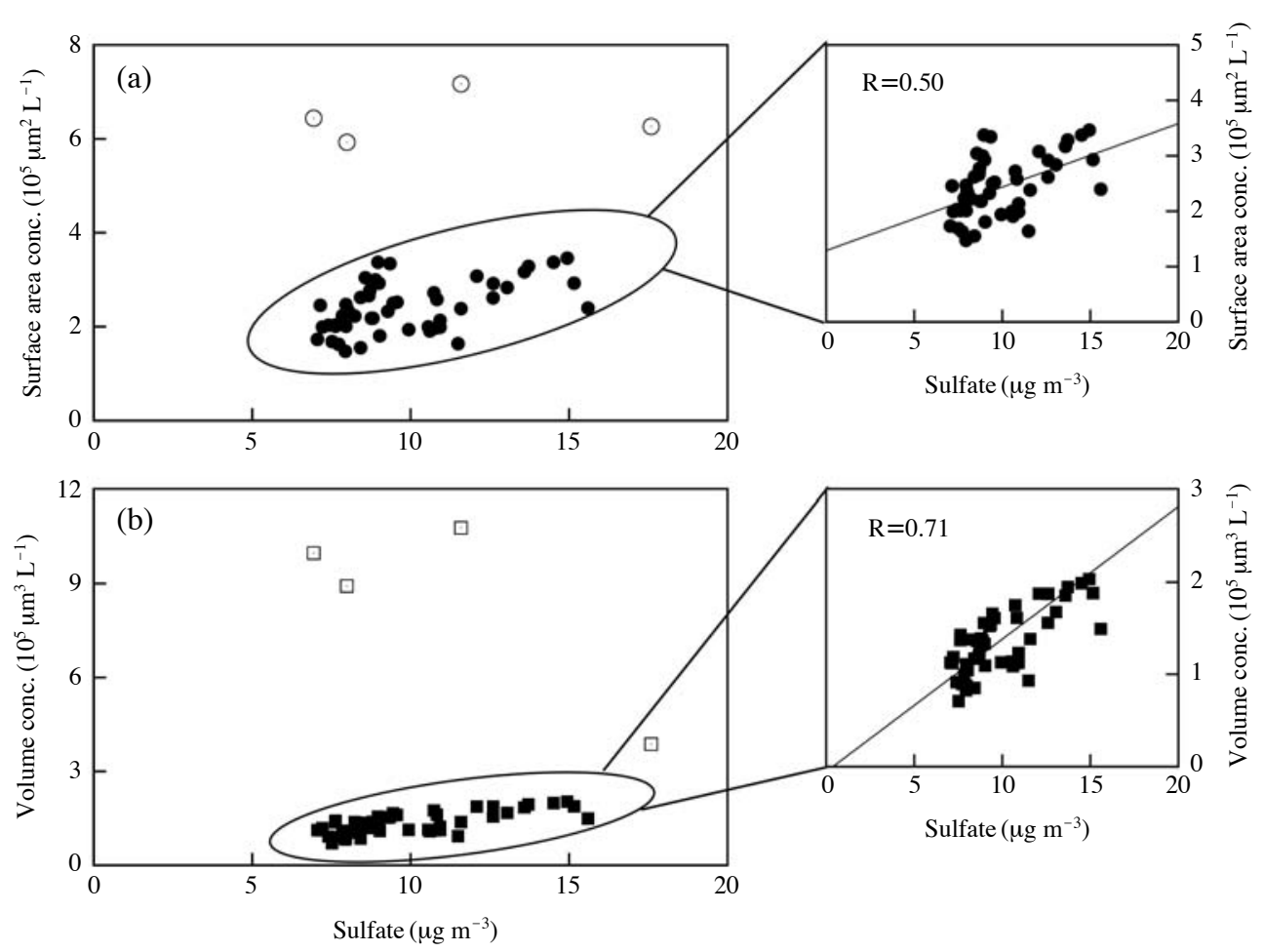

Fig. 4. Scatter plots of sulfate concentration versus total aerosol surface area concentration (a) and volume concentration (b) in the range of 0.1-2 $\mu \mathrm{m}$ particles during high concentration events (15, 18, 19-20, 20-21, 25-26 March, 2, 3, 5-6 and 6-7 April 2010). Open boxes and circles indicate the data of the extreme Asian dust event on 21 March 2010, which were excluded in the correlation coefficient $(\mathrm{R})$ calculation. 
high sulfate episode occurred around 1100-1700 on 18 March after the high-pressure center passed. The backward trajectories show that the corresponding air parcels were from northeastern China.

Increases of sulfate with a little increased $\mathrm{SO}_{2}$ also occurred when cold fronts passed the south part of Kyushu area. For example, increases of sulfate were observed during 10-14 March after a cyclone, and relatively high concentrations of both sulfate and $\mathrm{SO}_{2}$ were observed in the prefrontal and postfrontal air on 5 April.

\section{2 Sulfate and Aerosol Particles}

In order to investigate the dependence of the sulfate on particles in different size ranges, correlation coefficients $(\mathrm{R})$ of sulfate with volume and surface area concentrations of particles in the range of 0.1-2 $\mu \mathrm{m}$ during the high sulfate episodes were calculated. All particles were assumed in a spherical shape. Fig. 4 shows scatter plots of sulfate versus total aerosol volume concentration and surface area concentration. After excluding the data of 21 March when an extreme dust event passed, a good correlation $(\mathrm{R}=0.71)$ is confirmed between aerosol volume and sulfate concentrations. The correlation between surface area concentration and sulfate concentration is poor $(\mathrm{R}=0.50)$. These results indicate that sulfate was in principle present inside the particles rather than their surface. The variation of the number concentration of fine mode particles is usually depen- dent on the pollution status of air parcels; a typical chemical composition for continental fine mode particles in troposphere is sulfate $(37 \%)$, organic carbon (24\%), ammonium (11\%), and etc (Heintzenberg, 1989).

The increase of coarse mode particles in southwestern Japan in spring is usually caused by Asian dust which originates from the arid and semi-arid areas in the Asian continent (Iwasaka et al., 1988; Duce et al., 1980). The particles are usually characterized by mineral components frequently mixed with sea salt and the size range of larger than $1 \mu \mathrm{m}$ (Zhang et al., 2003; Okada et al., 1991). Asian dust events also appeared during our observation on 16, 20, 21 March and 3 April, after the passage of cyclones. In particular, an extreme dust event occurred on 20 and 21 March when the number concentration of particles $>5 \mu \mathrm{m}$ increased from $10 \mathrm{~L}^{-1}$ up to about $3800 \mathrm{~L}^{-1}$ after the cyclone, accompanied by a dramatic increase of sulfate. Close examinations of the time series of sulfate and particle number concentrations reveal that there were slight time lags between peaks of sulfate and those of number concentration of Asian dust in all dust events. The maximum sulfate and fine-mode particles appeared first, and then coarse-mode particles started to increase. Fig. 5 shows the cases on 16 and 20-21 March. Similar time lags between anthropogenic aerosols and Asian dust were reported by Uematsu et al. (2002) who summarized that sulfur particles appeared first and dust parti-

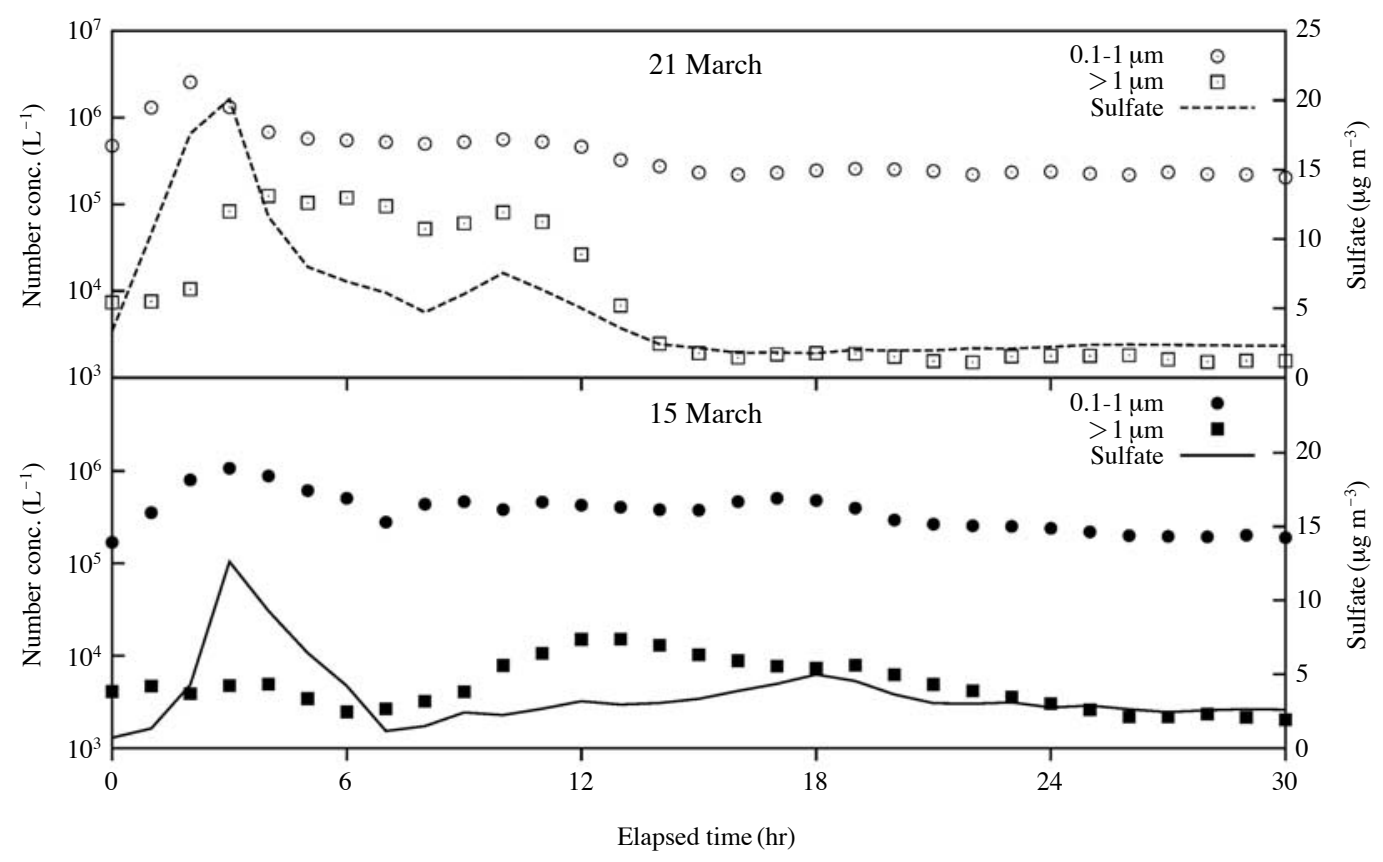

Fig. 5. Elapsed time series of sulfate concentration and fine and coarse-mode particle number concentrations after the frontal passages on 15 and 21 March 2010. 
cles arrived 12 hours later at $\operatorname{Nagasaki}\left(33^{\circ} \mathrm{N}, 130^{\circ} \mathrm{E}\right)$, a city in the upwind area of AERU (Fig. 1). In the present results, the time lag of sulfate and coarse-mode particles were 9 hours for the case on 16 March and 2 hours for the case on 20-21 March. Thus, mixture states of dust and sulfate were extremely inhomogeneous and varied case by case, whereas fine mode particles can be applied as an index showing the evolution of sulfate.

\section{3 Episodic Increase of $\mathrm{SO}_{2}$}

Investigation of variations of $\mathrm{SO}_{2}$ upon meteorological conditions revealed that episodic increases of $\mathrm{SO}_{2}$ also appeared around the passage of cyclones. An example of surface weather charts (at 150015 March) when $\mathrm{SO}_{2}$ concentration was $5.59 \mathrm{ppbv}$, and the isentropic backward trajectories for the high-SO $\mathrm{S}_{2}$ episodes on 14, 15, 22, 30-31 March, and 4, 10 April are also shown in Fig. 3. The episodic $\mathrm{SO}_{2}$ increases occurred in the prefrontal air when a high-pressure system existed at the northwestern Pacific Ocean to the east of Japan. The cyclones appeared in southeastern China and moved to southwestern Japan. Backward trajectories and wind directions indicate that the air parcels with high $\mathrm{SO}_{2}$ were from offshore ocean areas and passed Mt. Sakurajima before arriving at AERU. Therefore, we consider the $\mathrm{SO}_{2}$ in the air parcels to be mainly from the emission of the active volcano Mt. Sakurajima. According to the records of Kagoshima Local Meteorological Observatory, Mt. Sakurajima erupted 135 times and $\mathrm{SO}_{2}$ emission was estimated 1200-2000 ton /day during March 2010. According to the backward trajectory analysis, the air parcel was transported from Mt. Sakurajima to Amakusa within 3-7 hours. In addition, eruptions with volcanic plumes rising up to 1000 $1800 \mathrm{~m}$ were recorded at the times corresponding to all the high $\mathrm{SO}_{2}$ episodes in our observation. Thus, it is plausible that the episodic high $\mathrm{SO}_{2}$ were of volcanic origin. In an early previous case study, high $\mathrm{SO}_{2}$ influenced by Mt. Sakurajima was observed in elevated layers in Kyushu at the time of high pressure system leaving away from this area and the weather charts were similar to that shown in Fig. 3(c) (Uno et al., 1997).

\section{4 Conversion of $\mathrm{SO}_{2}$ to Sulfate}

The ratio of the sulfate concentration $\left(\mathrm{SO}_{4}{ }^{2-}\right)$ to total sulfur compounds $\left(\mathrm{SO}_{\mathrm{x}}\right)\left(=\left(\mathrm{SO}_{4}{ }^{2-}\right)+\left(\mathrm{SO}_{2}\right)\right)$ is an effective index for the extent of conversion of $\mathrm{SO}_{2}$ to sulfate in air parcels (Sahu et al., 2009; Miyakawa et al., 2007), assuming that total sulfate was dominated by the sulfate in $\mathrm{PM}_{2.5}$. Fig. 6 shows the scatter-plot of $\left(\mathrm{SO}_{4}{ }^{2-}\right) /\left(\mathrm{SO}_{\mathrm{x}}\right)$ versus relative humidity in the continentally and volcanically originated air parcels. The $\left(\mathrm{SO}_{4}{ }^{2-}\right)$

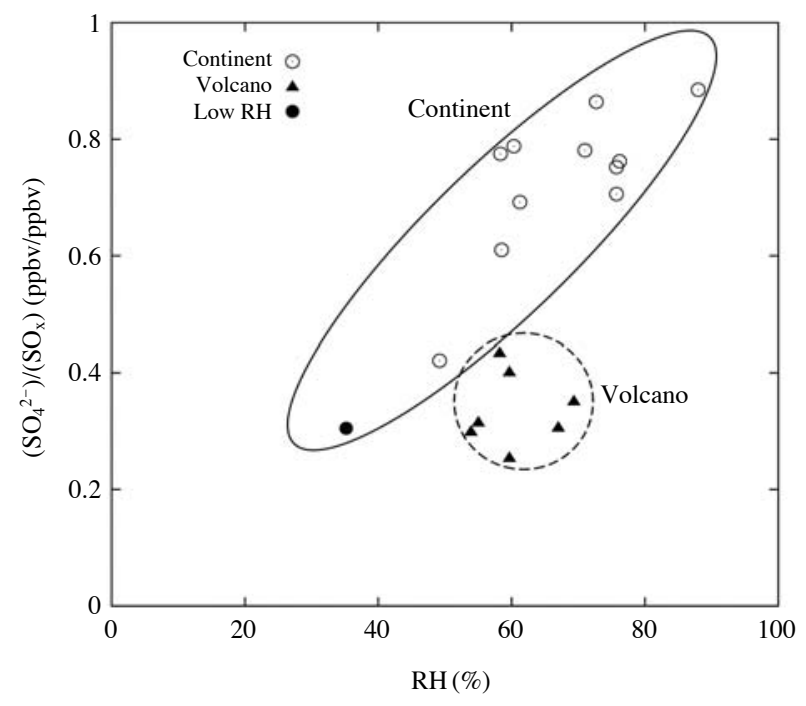

Fig. 6. Scatter plot of the ratio $\left(\mathrm{SO}_{4}{ }^{2-}\right) /\left(\mathrm{SO}_{\mathrm{x}}\right)$ versus relative humidity of the continental and volcanic air parcels. Continental air parcels were observed on 15, 18, 19-20, 20-21, 25-26 March, 2, 3, 5-6 and 6-7 April 2010. Volcanic air parcels were observed on 14, 15, 22, 30-31 March, 4 and 10 April 2010.

$/\left(\mathrm{SO}_{\mathrm{x}}\right)$ in the continentally originated air parcels varies between 0.31 and 0.89 with the average 0.65 (standard deviation 0.22). The value is similar to those observed during aircraft observations over the Sea of Japan, the Yellow Sea, and the northwestern Pacific, from surface to $1 \mathrm{~km}$ elevation (Jacob et al., 2003; Koike et al., 2003). In contrast, $\left(\mathrm{SO}_{4}{ }^{2-}\right) /\left(\mathrm{SO}_{\mathrm{x}}\right)$ in the volcanically originated air parcels ranges $0.25-0.43$ with the average 0.35 (standard deviation 0.10 ). The values are significantly smaller than those in the continentally originated air parcels, plotting within a different area in Fig. 6.

In order to obtain insights of $\mathrm{SO}_{2}$-to-sulfate conversion in the air parcels during the long-range transport, we compare the concentrations of sulfur compounds and $\left(\mathrm{SO}_{4}{ }^{2-}\right) /\left(\mathrm{SO}_{\mathrm{x}}\right)$ ratios obtained in this study with those from observations at various locations in the eastern Asia. Table 2 shows the averages of $\mathrm{SO}_{2}$ and sulfate concentrations and $\left(\mathrm{SO}_{4}{ }^{2-}\right) /\left(\mathrm{SO}_{\mathrm{x}}\right)$ in continentally originated air observed at AERU, along with previously published data observed at Lin'an, China $\left(30^{\circ} 25^{\prime} \mathrm{N}\right.$, $119^{\circ} 44^{\prime} \mathrm{E}$ ) (Wang et al., 2004) and at Gosan, South Korea $\left(33^{\circ} 17^{\prime} \mathrm{N}, 126^{\circ} 10^{\prime} \mathrm{E}\right)$ (Sahu et al., 2009). Extremely high $\mathrm{SO}_{2}$ and sulfate concentrations have been reported in China (Takegawa et al., 2009; Li et al., 2007; Wang et al., 2004). At Lin'an, a background observatory in polluted regions in eastern China located about $1000 \mathrm{~km}$ west of AERU, $\mathrm{SO}_{2}$ and sulfate concentrations in the spring of 2001 were $15.9 \pm 14.6 \mathrm{ppbv}$ and $17.3 \pm 6.6 \mu \mathrm{g} \mathrm{m}^{-3}$, respectively (Wang et al., 2004). 
Table 2. Inter-comparison of $\mathrm{SO}_{2}$ and sulfate concentrations and $\left(\mathrm{SO}_{4}{ }^{2-}\right) /\left(\mathrm{SO}_{\mathrm{x}}\right)$ ratios observed at sites in China, South $\mathrm{Korea}$ and AERU. The data are shown in averages with standard deviations.

\begin{tabular}{lccccc}
\hline & $\mathrm{SO}_{2}(\mathrm{ppbv})$ & Sulfate $\left(\mu \mathrm{g} \mathrm{m}^{-3}\right)$ & $\left(\mathrm{SO}_{4}{ }^{2-} / \mathrm{SO}_{\mathrm{x}}\right)$ [ppbv/ppbv] & Observation periods & References \\
\hline Lin'an, China & $15.9 \pm 14.6$ & $17.3 \pm 6.6$ & $0.24 \pm 0.10$ & Feb-April, 2001 & Wang et al., 2004 \\
Gosan, South Korea & $3.1 \pm 2.9$ & $3.99 \pm 3.40$ & $0.26 \pm 0.12$ & March-April, 2005 & Sahu et al., 2009 \\
Amakusa, Japan & $0.77 \pm 1.00$ & $4.37 \pm 2.65$ & $0.66 \pm 0.19$ & March-April, 2010 & This study \\
\hline
\end{tabular}

Thus, $\left(\mathrm{SO}_{4}{ }^{2-}\right) /\left(\mathrm{SO}_{\mathrm{x}}\right)$ is $0.24 \pm 0.10$ at Lin'an. $\mathrm{SO}_{2}$ concentration as high as $96.5 \mathrm{ppbv}$ (averaged value 17.8 ppbv) was also observed during spring 2005 at downwind areas of Beijing, the capital city of China and located in northern China (Li et al., 2007). The in situ measurements during 2005 spring at Gosan, located about $350 \mathrm{~km}$ northwest of AERU, showed that $\mathrm{SO}_{2}$ and sulfate concentrations in air parcels from China were $3.1 \pm 2.9 \mathrm{ppbv}$ and $3.99 \pm 3.40 \mu \mathrm{g} \mathrm{m}^{-3}$, respectively (Sahu et al., 2009). The $\left(\mathrm{SO}_{4}{ }^{2-}\right) /\left(\mathrm{SO}_{\mathrm{x}}\right)$ at Gosan is $0.26 \pm 0.12$, not much different from the value at Lin'an. Compared to the observations in eastern China and South Korea, continentally originated air parcels in the present study show considerably high $\left(\mathrm{SO}_{4}{ }^{2-}\right) /$ $\left(\mathrm{SO}_{\mathrm{x}}\right)$ and reduced $\mathrm{SO}_{2}$ concentration.

Koike et al. (2003) reported that 55-75\% of $\mathrm{SO}_{\mathrm{x}}$ can be removed before the air parcels leave the Asian continent, the consequence of which is reduction of $\mathrm{SO}_{2}$ and sulfate concentrations at downwind areas such as South Korea and Japan. Sulfate concentration in the continentally originated air parcels observed at AERU was higher than those at Gosan. This result suggests that the conversion of $\mathrm{SO}_{2}$ to sulfate could compensate the loss of sulfate under certain conditions although the total sulfur compounds decreased as the air parcels moved eastward.

It appears that the rate of conversion of $\mathrm{SO}_{2}$ to sulfate was rapid during the transport from Asian continent to Japan after comparing the concentrations of sulfur compounds in China, South Korea, and Japan. Backward trajectories (Fig. 5(a)) show that the air parcels with high sulfate arrived at AERU after passing through either Lin'an, Gosan or both. Assuming that the data in Table 2 represent typical concentrations of sulfur compounds during every spring, the much higher $\left(\mathrm{SO}_{4}{ }^{2-}\right) /\left(\mathrm{SO}_{\mathrm{x}}\right)$ at AERU than at the others indicates that $\mathrm{SO}_{2}$ in the air was efficiently converted to sulfate en route from Lin'an and Gosan to AERU. We infer that the high conversion efficiency was due to the humid maritime environment over the East China Sea. Before arriving at Gosan, the air experienced a very short time of marine environment where humid air must be entrained into the air parcels, but the time was likely too short for an efficient conversion. After passing Gosan, the air parcels continued to move in the marine environment until they arrived at AERU, and this accelerated the conversion under humid conditions. Consequently, sulfur compounds in the air parcels observed at AERU were mainly in the form of sulfate while $\mathrm{SO}_{2}$ occupied a smaller fraction in the total sulfur compounds.

Humidity is a key factor influencing the conversion efficiency, water vapor in the air parcels enhancing the conversion (Jacob, 1999; Seinfeld and Phandis, 1998). In particular, the conversion and removal of $\mathrm{SO}_{2}$ in the pre- and post-frontal air of cyclones are expected be much more rapid than under other conditions. Episodic sulfate increases at AERU were always present in air parcels of high humidity (Fig. 2). The correspondent relative humidity of air parcels with sulfate concentration larger than $10 \mu \mathrm{g} \mathrm{m}^{-3}, 5-10 \mu \mathrm{g} \mathrm{m}^{-3}$ and less than $5 \mu \mathrm{g} \mathrm{m}^{-3}$ were $70.0 \pm 9.9 \%, 63.5 \pm 12.3 \%$, and $58.4 \pm 17.0 \%$, respectively. In consequence, the $\left(\mathrm{SO}_{4}{ }^{2-}\right)$ $/\left(\mathrm{SO}_{\mathrm{x}}\right)$ ratios in continentally originated air parcels also show a dependence on humidity (Fig. 6). The dependence of the conversion efficiency on humidity can be further supported by the data around 17 March when the air parcel was from the northwestern China and Korean peninsula. During the episode, $\mathrm{SO}_{2}$ concentration was $1.77 \pm 0.34 \mathrm{ppbv}$, higher than the local average but much lower than in the air parcels influenced by volcanic gases. Sulfate concentration was $3.19 \mu \mathrm{g}$ $\mathrm{m}^{-3}$, lower than the local average. The ratio of $\left(\mathrm{SO}_{4}{ }^{2-}\right) /$ $\left(\mathrm{SO}_{\mathrm{x}}\right)$ for the episode was the smallest $(0.31 \pm 0.07)$ of all the high sulfate episodes. Even if $\mathrm{SO}_{2}$ might have been entrained at Korean peninsula, the small value indicates a lower conversion efficiency than in the other continentally originated air parcels (Fig. 6). The major difference of the air during this episode from the others was the low humidity $(35.2 \pm 5.38 \%)$. Dry and stable layers with enhanced $\mathrm{SO}_{2}$ which were originated from East Asia have been also observed over the Pacific ( $\mathrm{Tu}$ et al., 2004).

In contrast to the continentally originated air parcels, no obvious correlation is confirmed between $\left(\mathrm{SO}_{4}{ }^{2-}\right) /$ $\left(\mathrm{SO}_{\mathrm{x}}\right)$ ratio and relative humidity in the air parcels of episodic $\mathrm{SO}_{2}$ that had passed the volcano Mt. Sakurajima. The $\left(\mathrm{SO}_{4}{ }^{2-}\right) /\left(\mathrm{SO}_{\mathrm{x}}\right)$ ratios are usually smaller than those for the continentally originated air parcels despite rather high relative humidity (Fig. 6). The reason for the absence of the correlation is probably the short time for $\mathrm{SO}_{2}$ to be converted to sulfate because it takes 
only a few hours for the air parcels to arrive at AERU after passing the volcano. Based on all these results, we suggest that the efficient conversion of $\mathrm{SO}_{2}$ to sulfate in continentally originated air is the major reason why high $\mathrm{SO}_{2}$ was rarely observed around Japanese islands when air parcels from the Asian continent with high sulfate were frequently encountered. Note that the arrivals of all the air parcels discussed above were not accompanied with precipitation.

\section{CONCLUSIONS}

Observations at AERU, located on the Japan southwestern coast in spring 2010, revealed episodic but not mutually correlated increases of particulate sulfate in $\mathrm{PM}_{2.5}$ and gaseous $\mathrm{SO}_{2}$. The episodic sulfate increases were caused by air parcels from the Asian continent and Korea peninsula. Their maxima reached 10.5-20.1 $\mu \mathrm{g} \mathrm{m}^{-3}$ although the average in the whole observation period was $4.4 \pm 2.7 \mu \mathrm{g} \mathrm{m}^{-3}$. The variation of sulfate concentration always synchronized with and correlated well with the volume concentration of aerosol particles in the size range of $0.1-0.5 \mu \mathrm{m}$, indicating the presence of the sulfate was a consequence of $\mathrm{SO}_{2}$ oxidation and accumulation in associated with particles in the submicron range. In contrast, the episodic $\mathrm{SO}_{2}$ was found to have been caused by emissions from a volcano, Mt. Sakurajima, approximately $100 \mathrm{~km}$ in the south. Detailed analyses of the observed data during the passage of dust-loading low pressures revealed differences in phase between sulfate and dust concentrations, suggesting an isolated status of the air with maximum sulfate from dusty one. The ratio of sulfate to total sulfur compounds ranged $0.31-0.89$ in continentally originated air while it was $0.25-0.43$ in the air having passed over the volcano. A close dependence of the conversion of $\mathrm{SO}_{2}$ to sulfate on humidity in the continentally originated air was confirmed. The present results suggest that, on the southwest Japan coast in spring, sulfur compounds in the continentally originated air parcels are mainly in the state of particulate sulfate, while substantial increases of $\mathrm{SO}_{2}$ are usually due to emissions from volcanic activities close to the area.

\section{ACKNOWLEDGEMENT}

The setup of AERU was supported by the Research Fund from Regional Cooperation Center of Prefectural University of Kumamoto, and partly by the Grant-inAid for Scientific Research of JSPS (No. 17684026). The observations were supported by the Asahi Breweries Foundation. Authors thank Prof. Jay Melton for his revision of word and grammar.

\section{REFERENCES}

Andreae, M.O., Berresheim, H., Andreae, T.W., Kritz, M.A., Bates, T.S., Merrill, J.T. (1988) Vertical distribution of dimethylsulfide, sulfur dioxide, aerosol ions, and radon over the northeast Pacific Ocean. Journal of Atmospheric Chemistry 6(1-2), 149-173.

Bates, T.S., Quinn, P.K., Coffman, D.J., Covert, D.S., Miller, T.L., Johnson, J.E., Carmichael, G.R., Guazzotti, S.A., Sodeman, D.A., Prather, K.A., Rivera, M., Russell, L.M., Merrill, J.T. (2004) Marine boundary layer dust and pollutant transport associated with the passage of a frontal system over eastern Asia. Journal of Geophysical Research, 109, D19S19, doi:10.1029/2003J D004094.

Charlson, R.J., Schwartz, S.E.,. Hales, J.M, Cess, R.D., Coakley, J.A. Jr., Hansen, J.E., Hofmann, D.J. (1992) Climate forcing by anthropogenic aerosol. Science 255, 423-430.

Chuang, C.C., Penner, J.E., Taylor, K.E., Grossman, A.S., Walton, J.J. (1997) An assessment of the radiative effects of anthropogenic sulfate. Journal of Geophysical Research 102, 3761-3778.

Dentener, F.J., Carmichael, G.R., Zhang, Y., Lelieveld, J., Crutzen, P.J. (1996) Role of mineral aerosol as a reactive surface in the global troposphere. Journal of Geophysical Research, 101, 22869-22889.

Draxler, R.R., Rolph, G.D. (2003) HYSPLIT (Hybrid Single-Particles Lagrangian Integrated Trajectory) Model access via NOAA ARL READY Website (http://www. arl. noaa.gov/ready/hysplit4.html). NOAA Air Resources Laboratory, Silver Spring, MD.

Duce, R.A., Unni, C.K., Ray, B.J., Prospero, J.M., Merrill, J.T. (1980) Long-range atmospheric transport of soil dust from Asia to the tropical North Pacific: Temporal variability. Science 209, 1522-1524.

Hatakeyama, S., Takami, A., Sakamaki, F., Mukai, H., Sugimoto, N., Shimizu, A., Bandow, H. (2004) Aerial Measurement of Air Pollutants and Aerosols during March 20-22, 2001, over the East China Sea. Journal of Geophysical Research, 109: D13304, doi:10.1029/ 2003JD004271.

Heald, C.L., Jacob, D.J., Park, R.J., Alexander, B., Fairlie, D., Yantosca, R.M., Chu, A. (2006) Transpacific transport of Asian anthropogenic aerosols and its impact on surface air quality in the United States. Journal of Geophysical Research, 111, D14310, doi:10.1029/2005JD 006847.

Heintzenberg, J. (1989) Fine particles in the global troposphere: A review. Tellus, Ser. B 41, 149-160.

Hewitt, C.N. (2001) The atmospheric chemistry of sulphur and nitrogen in power station plumes. Atmospheric Environment 35, 1155-1170.

Huebert, B.J., Phillips, C.A., Zhuang, L., Kjellström, E., 
Rodhe, H., Feichter, J., Land, C. (2001) Long-term measurements of free-tropospheric sulfate at Mauna Loa: Comparison with global model simulations. Journal of Geophysical Research 106(D6), 5479-5492.

Igarashi, Y., Sawa, Y., Yoshioka, K., Matsueda, H., Fuji, K., Dokiya, Y. (2004) Monitoring the $\mathrm{SO}_{2}$ concentration at the summit of Mt. Fuji and a comparison with other trace gases during winter. Journal of Geophysical Research 109, D17304, doi:10.1029/2003JD004428.

Iwasaka, Y., Yamato, M., Imasu, R., Ono, A. (1988) Transport of Asian dust (KOSA) particles; importance of weak KOSA events on the geochemical cycle of soil particles. Tellus 40B, 494-503.

Jacob, D. (1999) Introduction to Atmospheric Chemistry, Princeton, NJ: Princeton Univ. Press.

Jacob, D.J., Crawford, J.H., Kleb, M.M., Connors, V.S., Bendura, R.J., Raper, J.L., Sachse, G.W., Gille, J.C., Emmons, L., Heald, C.L. (2003) Transport and Chemical Evolution over the Pacific (TRACE-P) aircraft mission: Design, execution, and first results. Journal of Geophysical Research 108(D20), 9000, doi:10.1029/ 2002JD003276.

Jaffe, D.A., Anderson, T., Covert, D., Kotchenruther, R., Trost, B., Danielson, J., Simpson, W., Bertsen, T., Karlsdottir, S., Blake, D., Harris, J., Carmichael, G., Uno, I. (1999) Transport of Asian air pollution to North America. Geophysical Research Letter 26, 711-714.

Koike, M., Kondo, Y., Kita, K., Takegawa, N., Masui, Y., Miyazaki, Y., Ko, M.W., Weinheimer, A.J., Flocke, F., Weber, R.J., Thornton, D.C., Sachse, G.W., Vay, S.A., Blake, D.R., Streets, D.G., Eisele, F.L., Sandholm, S.T., Singh, H.B., Talbot, R.W. (2003) Export of anthropogenic reactive nitrogen and sulfur compounds from the East Asia region in spring. Journal of Geophysical Research 108(D20), 8789, doi:10.1029/2002JD003284.

Li, C., Marufu, L.T., Dickerson, R.R., Li, Z., Wen, T., Wang, Y., Wang, P., Chen, H., Stehr, J.W. (2007) In situ measurements of trace gases and aerosol optical properties at a rural site in northern China during East Asian Study of Tropospheric Aerosols: An International Regional Experiment 2005. Journal of Geophysical Research 112, D22S04, doi:10.1029/2006JD007592.

Lovelock, J.E., Maggs, R.J., Rasmussen, R.A. (1972) Atmospheric dimethylsulfide and the natural sulfur cycle. Nature 237, 452-453.

Lu, Z., Streets, D.G., Zhang, Q., Wang, S., Carmichael, G.R., Cheng, Y.F., Wei, C., Chin, M., Diehl, T., Tan, Q. (2010) Sulfur dioxide emissions in China and sulfur trends in East Asia since 2000. Atmospheric Chemistry and Physics Discuss 10, 8657-8715.

Luria, M., Sievering, H. (1991) Heterogeneous and homogeneous oxidation of $\mathrm{SO}_{2}$ in the remote marine atmosphere. Atmospheric Environment 25A, 1489-1496.

Miyakawa, T., Takegawa, N., Kondo, Y. (2007) Removal of sulfur dioxide and formation of sulfate aerosol in Tokyo. Journal of Geophysical Research 112, D13209, doi:10.1029/2006JD007896.

Ohara, T., Akimoto, H., Kurokawa, J., Horii, N., Yamaji,
K., Yan, X., Hayasaka, T. (2007) An Asian emission inventory of anthropogenic emission sources for the period 1980-2020. Atmospheric Chemistry and Physics 7, 4419-4444.

Okada, K., Heintzenberg, J., Kai, K., Qin, Y. (2001) Shape of atmospheric mineral particles collected in three Chinese arid-regions. Geophysical Research Letter 28, 3123-3126.

Prospero, J.M., Savoie, D.L., Arimoto, R. (2003) Long term record of nss-sulfate and nitrate in aerosols on Midway Island, 1981-2000: Evidence of increased (now decreasing?) anthropogenic emissions from Asia. Journal of Geophysical Research 108(D1), 4019, doi:10.1029 /2001JD001524.

Prospero, J.M., Uematsu, M., Savoie, D. (1989) Mineral aerosol transport to the Pacific Ocean. Chemical Oceanography 10, 188-218.

Robock, A. (2000) Volcanic eruptions and climate. Review of Geophysics, 38, 191-219.

Sahu, L.K., Kondo, Y., Miyazaki, Y., Kuwata, M., Koike, M., Takegawa, N., Tanimoto, H., Matsueda, H., Yoon, S.C., Kim, Y.J. (2009) Anthropogenic aerosols observed in Asian continental outflow at Jeju Island, Korea, in spring 2005. Journal of Geophysical Research 114, D03301, doi:10.1029/2008JD010306.

Savoie, D.L., Prospero, J.M. (1989) Comparison of oceanic and continental sources of non-sea-salt sulphate over the Pacific Ocean. Nature 339, 685-687.

Schwab, J.J., Hogrefe, O., Demerjian, K.L., Dutkiewicz, V.A., Husain, L., Rattigan, O.V., Felton, H.D. (2006) Field and laboratory evaluation of the Thermo Electron 5020 Sulfate Particulate Analyzer. Aerosol Science and Technology 40, 744-752.

Seinfeld, J.H., Pandis, S.N. (1998) Atmospheric Chemistry and Physics: From Air Pollution to Climate Change John Wiley, NewYork, 1326 pp.

Solomon, S. (1999) Stratospheric ozone depletion: A review of concepts and history. Review of Geophysics $37,275-316$.

Streets, D.G., Bond, T.C., Carmichael, G.R., Fernandes, S.D., Fu, Q., He, D., Klimont, Z., Nelson, S.M., Tsai, N.Y., Wang, M.Q., Woo, J.-H., Yarber, K.F. (2003) An inventory of gaseous and primary aerosol emissions in Asian in the year 2000. Journal of Geophysical Research 108 (D21), 8809, doi:10.1029/2002JD003093.

Streets, D.G., Tsai, N.Y., Akimoto, H., Oka, K. (2000) Sulfur dioxide emissions in Asia in the period 19851997. Atmospheric Environment 34, 4413-4424.

Takegawa, N., Miyakawa, T., Kuwata, M., Kondo, Y., Zhao, Y., Han, S., Kita, K., Miyazaki, Y., Deng, Z., Xiao, R., Hu, M., van Pinxteren, D., Herrmann, H., Hofzumahaus, A., Holland, F., Wahner, A., Blake, D.R., Sugimoto, N., Zhu, T. (2009) Variability of submicron aerosol observed at a rural site in Beijing in the summer of 2006. Journal of Geophysical Research 114, D00G05, doi:10.1029/2008JD010857.

Takemura, T., Nakajima, T., Higurashi, A., Ohta, S., Sugimoto, N. (2003) Aerosol distributions and radiative 
forcing over the Asian Pacific region simulated by Spectral Radiation-Transport Model for Aerosol Species (SPRINTARS). Journal of Geophysical Research 108 (D23), 8659, doi:10.1029/2002JD003210.

Tu, F.H., Thornton, D.C., Bandy, A.R., Carmichael, G.R., Tang, Y., Thornhill, K.L., Sachse, G.W., Blake, D.R. (2004) Long-range transport of sulfur dioxide in the central Pacific. Journal of Geophysical Research 109, D15S08, doi:10.1029/2003JD004309.

Uematsu, M., Yoshikawa, A., Muraki, H., Arao, K., Uno, I. (2002) Transport of mineral and anthropogenic aerosols during a Kosa event over East Asia. Journal of Geophysical Research 107(D7), 4059, doi:10.1029/ 2001JD000333.

Uno, I., Carmichael, G.R., Streets, D.G., Tang, Y., Yienger, J.J., Satake, S., Wang, Z., Woo, J.H., Guttikunda, S., Uematsu, M., Matsumoto, K., Tanimoto, H., Yoshioka, K., Iida, T. (2003) Regional Chemical Weather Forecasting System CFORS: Model Descriptions and Analysis of Surface Observations at Japanese Island Stations during the ACE-Asia Experiment. Journal of Geophysical Research 108:8668, doi:10.1029/2002JD 002845.

Uno, I., Wakamatsu, S., Ueda, H., Murano, K., Sakamaki, S., Kurita, H., Satsumabayshi, H., Horai, S. (1997) Behavior of secondary pollutants an volcanic $\mathrm{SO}_{2}$ over Kyushu during a spring high pressure system. Journal of Japan Society for Atmospheric Environment 32, 404-424.

Wang, T., Wong, C.H., Cheung, V.T.F., Blake, D.R., Bau- mann, K., Arimoto, R., Tang, J., Ding, G.A., Yu, X.M., Li, Y.S. (2004) Relationships of trace gases and aerosols and the emission characteristics at Lin'an, a rural site in eastern China during spring 2001. Journal of Geophysical Research 109, D19S05, doi:10.1029/ 2003JD004119.

Zhang, D., Iwasaka, Y., Matsuki, A., Ueno, K., Matsuzaki, T. (2006) Coarse and accumulation mode particles associated with Asian dust in southwestern Japan. Atmospheric Environment 40(7), 1205-1215.

Zhang, D., Iwasaka, Y., Shi, G., Zang, J., Matsuki, A., Trochkine, D. (2003) Mixture state and size of Asian dust particles collected at southwestern Japan in spring 2000. Journal of Geophysical Research 108, 4760, doi: 10.1029/2003JD003869.

Zhang, D., Zang, J., Shi, G., Iwasaka, Y., Matsuki, A., Trochkine, D. (2003) Mixture state of individual Asian dust particles at a coastal site of Qingdao, China. Atmospheric Environment 37, 3895-3901.

Zhang, Q., Streets, D.G., Carmichael, G.R., He, K., Huo, H., Kannari, A., Klimont, Z., Park, I., Reddy, S., Fu, J.S., Chen, D., Duan, L., Lei, Y., Wang, L., Yao, Z. (2009) Asian emissions in 2006 for the NASA INTEXB mission. Atmospheric Chemistry and Physics. Discuss. 9, 4081-4139.

(Received 1 December 2011, revised 4 February 2012, accepted 13 February 2012) 